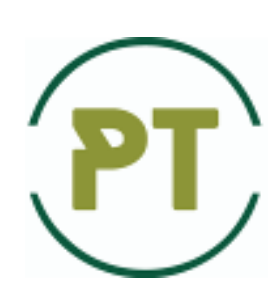

Problems of Tribology

Website: http://tribology.khnu.km.ua/index.php/ProbTrib

E-mail: tribosenator@gmail.com

DOI: https://doi.org/10.31891/2079-1372-2021-101-3-42-47

\title{
Development of methods for evaluation of lubrication properties of hydraulic aviation oils
}

\author{
T.A. Ilina, O.O. Mikosianchyk, R.H. Mnatsakanov, O.Ye. Yakobchuk \\ National Aviation University, Ukraine \\ *E-mail: oksana.mikos@ukr.net
}

Received: 10 May 2021: Revised: 24 August: Accept: 14 September 2021

\begin{abstract}
A method for evaluation of the lubricating and rheological properties of hydraulic oils in tribological contacts has been developed, which consists in online studying samples of commercial batches of oils on a software and hardware complex with visual evaluation of the kinetics of changes in the main tribological indicators of friction contact. Using a roller analogy, the operation of gears in the conditions of rolling with $30 \%$ sliding is simulated. Samples of AMG-10 oil from two producers are analyzed. It is established that with increasing temperature of lubricant for Sample 2 ("Kvalitet-Avia" AMG-10), a long-term restoration of protective boundary films of oil is observed and the period of their formation increases by 2.5 times, causing the implementation of a semidry mode of lubrication at start-up. The total thickness of the lubricating layer is 1.27 times less as compared with Sample 1 ("Bora B" AMG-10 oil), regardless of the lubricant temperature. Also, the rheological properties of the oils have been determined. Sample 1 exhibits low shear stresses at the level of 9.4 $\mathrm{MPa}$ and high effective viscosity, 4249 and $5039 \mathrm{~Pa} \cdot \mathrm{s}$, at a volumetric oil temperature of 20 and $100{ }^{\circ} \mathrm{C}$, respectively. For Sample 2, with increasing oil temperature to $100{ }^{\circ} \mathrm{C}$ shear stress increases by 1.15 times and the effective viscosity in contact decreases by 1.53 times. Additives present in Sample 1 are characterized by more effective antiwear properties and thus increase the wear resistance of contact surfaces in the conditions of rolling with sliding thanks to strengthening of the surface metal layers during operation, while Sample 2 undergoes strengthening-softening processes which reduce the wear resistance of friction pairs.
\end{abstract}

Key words: aviation oils, lubricating layer, lubrication mode, effective viscosity, microhardness.

\section{Introduction}

Routes to increase the wear resistance of triboconjuction elements are based on modification of contact surfaces via selecting lubricant compositions and finding optimal operating modes for friction pairs. An important factor in ensuring a high efficiency of friction units is a high-quality choice of lubricants with high lubricating, antifriction and antiwear characteristics. Among various producers of commercial oil batches, it is important to choose a lubricant that meets not only required physical and chemical characteristics, but also has effective tribological properties. However, tribological indicators have not yet been standardized for a wide range of lubricants. Therefore, the development of methods for evaluating the quality of lubricants in tribological contact is an important area of research, the results of which can make it possible to provide valuable recommendations on oil workabiity in certain operation modes.

\section{Literature review}

The aviation hydraulic system is designed to control the mechanisms and systems responsible for flight safety. Its durability, operational survivability and reliability provide perfection of the design of units. Aviation hydraulic systems include forced hydraulic pumps. Ensuring their efficiency requires a high level of tribological properties of oils. 
In particular, oils for aviation hydraulic systems must have an optimal level of viscosity, high viscositytemperature properties in a wide temperature range and resistance to oxidation and foam formation. Oils must also have a sufficient level of tribological characteristics and be compatible with the structural and sealing materials of the components and units of the hydraulic system. A reduced viscosity of hydraulic oils causes the most intense manifestation of fatigue wear of the contacting parts of the hydraulic system. An increased viscosity significantly increases the mechanical losses of the drive, complicates the relative movement of pump parts and valves as well as makes it impossible for hydraulic systems to operate at low temperatures.

In [1], physicochemical and operational properties of optimized oil samples have been studied in an extended range of qualification test methods. The performance properties of new oils were compared with regular counterparts using a system of comparative evaluation of oil quality. All the results of computational and experimental studies of the properties of prototypes were included in the electronic database, on the basis of which valuable recommendations were developed for the introduction of new oils.

Many aircrafts use the hydraulic aviation oil AMG-10 in their hydraulic systems. Its lubricity is quite sufficient to prevent wear of hydraulic devices. To ensure stability over a long service life (2 - 3 years), unsaturated hydrocarbons are removed from the AMG-10 oil base and an antioxidant additive is added. The main disadvantage of AMG-10 oil is its low fire safety ("flash point in an open crucible" does not exceed $90{ }^{\circ} \mathrm{C}$ ). In addition, during the operation of hydraulic systems with AMG-10 oil there observed a decrease in its viscosity due to the gradual destruction of the thickening additive. This leads to too rough operation of the mechanisms, oil overflow inside the hydraulic devices or to an external leak [2].

To improve the performance of oils for hydraulic systems, they are prepared from highly refined oil fractions with a viscosity index of not below 85 from low-sulfur and sulfur oils, which have undergone an acidbase or selective purification [3].

In [4], change in viscosity of AMG-10 oil in the temperature range $20-80{ }^{\circ} \mathrm{C}$ at a constant flow rate gradient has been analyzed. This fluid was established to change its rheological properties: at a temperature below $50{ }^{\circ} \mathrm{C}$ it is a Newtonian fluid, while at higher temperatures it becomes an Oswald de Ville fluid.

Analysis of publications on lubricating and rheological characteristics of oils for hydraulic systems has revealed that no comprehensive research in this direction has not been carried out yet. Therefore, study of the effective viscosity stability under mechanodynamic loads is of considerable interest.

\section{Purpose}

The purpose of the work is to develop a method for evaluating the lubricating and rheological properties of hydraulic oils in tribological contacts.

\section{Objects of research and experimental conditions}

Oils to be studied:

- sample 1 is oil "Bora B" AMG-10 according to TU U 19.2-38474081-010: 2016 with change 1 (produced by the LLC "Bora B", Ukraine);

- sample 2 is oil AMG-10 according to GOST 6794-75 with changes 1 - 5 (produced by the LLC "NPP Kvalitet", Russia).

Sample 1 was developed to organize work on avoiding oil import and overcome the critical dependence of the defense industry of Ukraine on import supplies of AMG-10 oil. The study of the samples was carried out on a software-hardware complex to evaluate the tribological characteristics of triboelements (Fig. 1), for which a special software had been developed for stepper motor control and online visual evaluation of the kinetics of changes in the main tribological parameters of tribocontact [5].

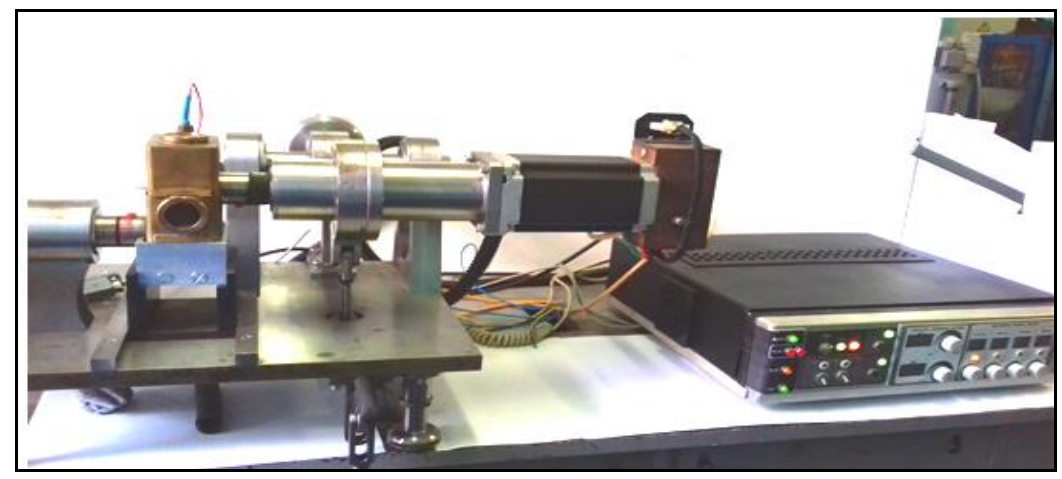

Fig. 1. Device for evaluation of tribological characteristics of triboelements

Work of gears in the conditions of rolling with sliding was modeled using the software-hardware complex by means of a roller analogy. Lubrication properties (hydrodynamic and non-hydrodynamic components of the 
lubricating film thickness) were determined by the method of voltage drop in the mode of normal glow discharge. Rheological characteristics of the lubricant (shear rate gradient, shear stress of lubricating layers, effective viscosity in contact) were evaluated by the kinetics of changes in the lubricating layer thickness, rotation speed of the leading and lagging surfaces and temperature of the lubricating layer.

Rollers (steel 30KhHSA, HRC $48 \ldots 52, \mathrm{Ra} 0.34 \mu \mathrm{m}$ ) were used as the material of contact surfaces. Lubrication of the contact surfaces was performed through immersing the lower roller in a bath of oil.

Testing was conducted in nonstationary conditions, which provide for the cyclicity of repetition in the start-up - stationary operation - braking - stop mode (Fig. 2). The total duration of the cycle was $80 \mathrm{~s}$.

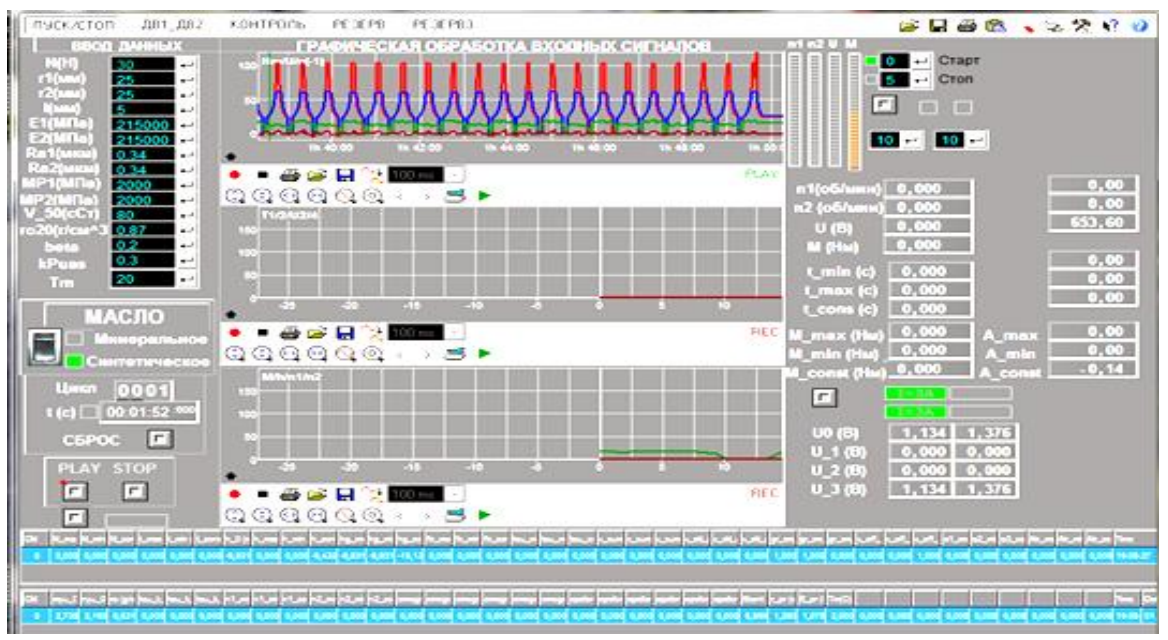

Fig. 2. Interface of subprogram for data processing during tribosystem operation in nonstationary friction conditions

Maximum rotation speed: $700 \mathrm{rpm}$ for the leading surface and $500 \mathrm{rpm}$ for the lagging surface. Sliding: 30\%. Maximum contact load by Hertz: $200 \mathrm{MPa}$. Total number of cycles: 100. Temperature of oil: $20^{\circ} \mathrm{C}$ (cycles 1 - 45), rise to $100{ }^{\circ} \mathrm{C}$ (cycles 46 - 50), $100{ }^{\circ} \mathrm{C}$ (cycles 51 - 100).

\section{Analysis of the main results}

The investigated oil "Bora B" AMG-10 (Sample 1) is characterized by effective lubricating properties both during start-up and at the maximum rotation speed (Fig. 3). With increasing temperature in the tribological contact there is observed a decrease in the thickness of boundary adsorption layers due to changes in their nature: boundary layers of predominantly physical nature are replaced by boundary layers of chemical nature characterized by more effective antiwear properties. No failure of the lubricating layer during start-up and direct metal contact of the friction surfaces has been established. A semidry lubrication mode was only revealed for a short time, namely during the periods of running-in and initial temperature rise.

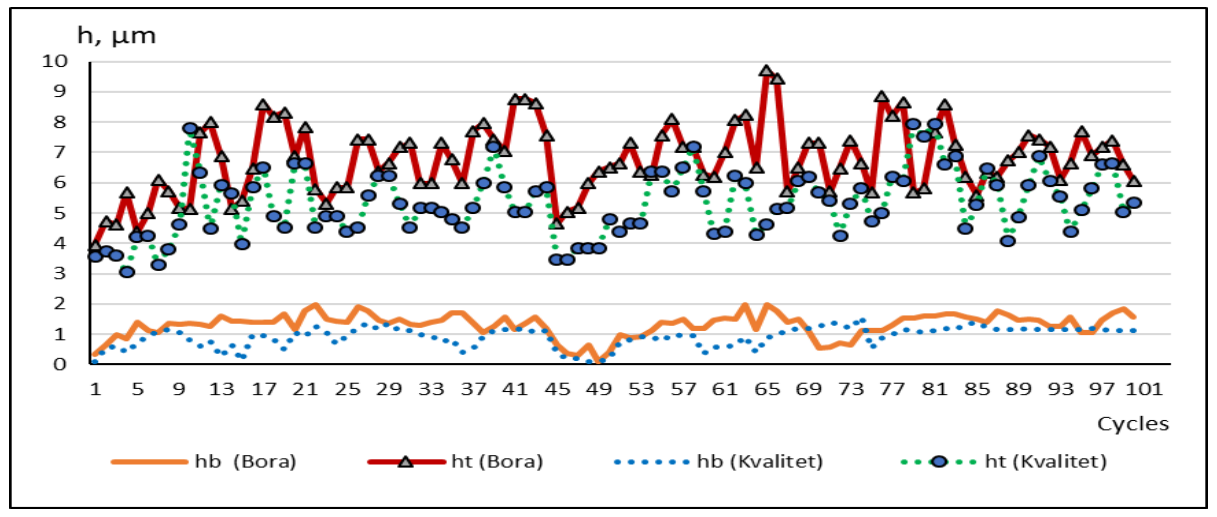

Fig. 3. The kinetics of change in the thickness

of the boundary adsorption layers $\left(h_{b}\right)$ and the total thickness of the lubricating layer $\left(h_{t}\right)$ in the contact in the course of operation

At start-up, a mixed lubrication mode dominates regardless of the lubricant temperature, which indicates the effective starting properties of Sample 1 (Fig. 4). 


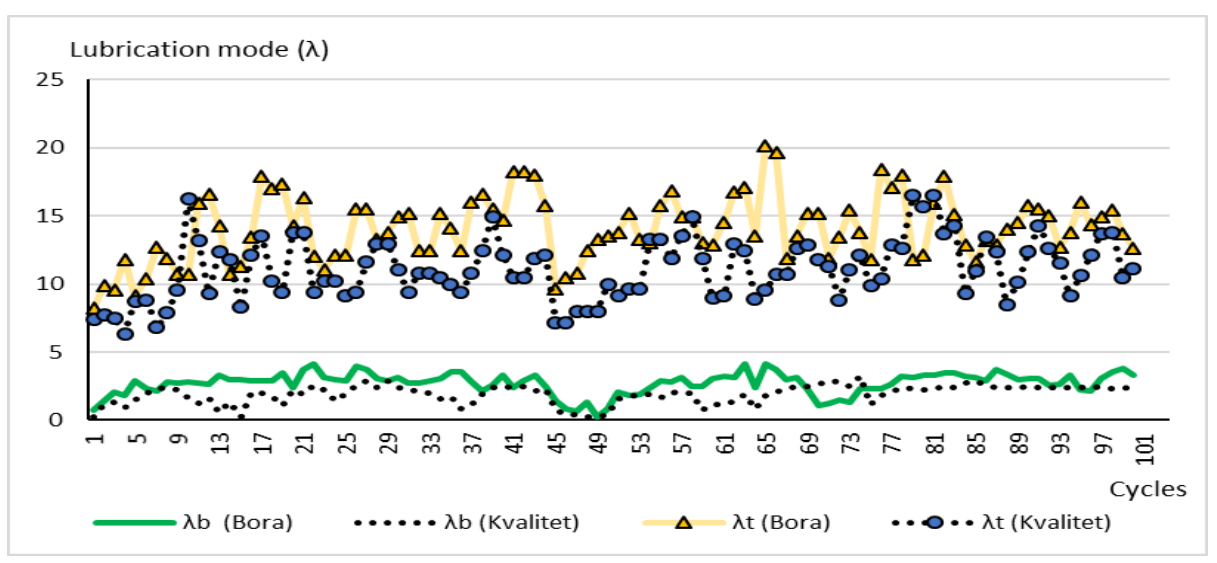

Fig. 4. The kinetics of change in lubrication modes in tribological contact (Classification of lubrication modes by $\lambda$ :

semidry $(\lambda=0 \ldots 1)$; boundary $(\lambda=1 \ldots 1.5)$; mixed $(\lambda=1.5 \ldots 3)$;

elastic-hydrodynamic (contact-hydrodynamic) $(\lambda=3 \ldots 4)$; hydrodynamic $(\lambda \geq 4))$

At maximum rotation speeds of the samples studied, the hydrodynamic mode of lubrication dominates, regardless of the oil temperature, which indicates effective separation of the contact surfaces due to formation of a lubricating layer.

Sample 2 (oil Kvalitet AMG-10) is characterized by effective lubricating properties at the maximum investigated rotation speeds, but during start-up its lubricating properties decrease (Fig. 3). At volumetric oil temperatures of 20 and $100{ }^{\circ} \mathrm{C}$, the boundary adsorption layer thickness is 0.88 and $0.95 \mu \mathrm{m}$, respectively, which is, on average, 1.44 times less than that for Sample 1. This leads to deterioration of the lubrication mode in contact during start-up and to dominance of the boundary lubrication mode in $25 \%$ of the operating cycles. With increasing lubricant temperature, a long recovery of the protective boundary oil films takes place, the time of their formation increases by 2.5 times as compared with Sample 1, thus causing the implementation of a semidry mode of lubrication at start-up.

At maximum rotation speeds of the samples, a hydrodynamic mode of lubrication dominates, regardless of the oil temperature, which indicates the effective separation of the contact surfaces due to the formation of a lubricating layer. The total lubricating layer thickness, which includes hydrodynamic and non-hydrodynamic components, is 1.27 times less compared with Sample 1, regardless of the lubricant temperature.

Let us analyze the kinetics of changes in the rheological characteristics of the oils studied.

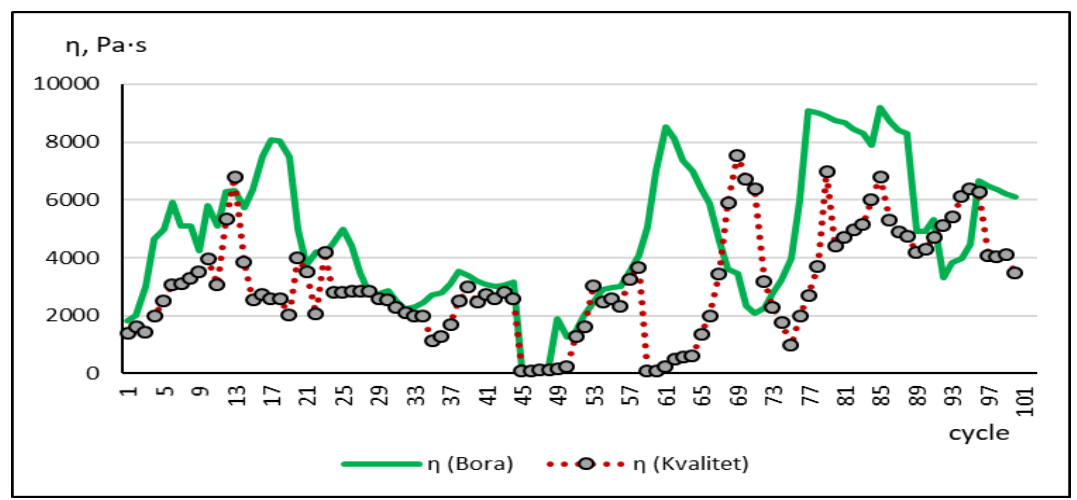

Fig. 5. The kinetics of change in the effective viscosity $(\eta)$ of oils in the contact

The "Bora B" AMG-10 oil is characterized by effective rheological properties. Ensuring the hydrodynamic mode of lubrication at maximum speeds of the cycle, in the conditions of rolling with $30 \%$ sliding is due to the high bearing capacity of the lubricant and formation of hydrodynamic and non-hydrodynamic components of the lubricating layer thickness which are characterized by low shear stress, on average, 9.4 MPa regardless of oil temperature.

Despite the high shear rate gradients in the contact lubricating layer, from $5.63 \cdot 10^{3}$ to $5.73 \cdot 10^{5} \mathrm{~s}^{-1}$, which occur at a maximum sliding speed of $0.71 \mathrm{~m} / \mathrm{s}$ in the conditions of rolling with sliding, the lubricant is characterized by effective viscosity, on average, 4249 and $5039 \mathrm{~Pa} \cdot \mathrm{s}$ at a volumetric oil temperature of 20 and $100{ }^{\circ} \mathrm{C}$, respectively (Fig. 5). This indicates good resistance of the oil components to destruction under conditions of increasing shear rate gradient. The greatest reduction in effective viscosity to $105 \quad \ldots 250 \mathrm{~Pa} \cdot \mathrm{s}$ occurs in the conditions of initial increase in oil temperature (45 - 49 test cycles). This is due to change in the nature of the boundary adsorption layers characterized by effective adaptation in a wide range of temperatures. 
Sample 2 (Kvalitet AMG-10 oil), similar to Sample 1, is characterized by effective rheological properties. The shear stress of the lubricating layers is, on average, $9.4 \mathrm{MPa}$ at an oil temperature of $20{ }^{0} \mathrm{C}$, which is close to that of Sample 1. When the oil temperature rises to $100{ }^{\circ} \mathrm{C}$, this parameter increases to $10.82 \mathrm{MPa}$, which is slightly, by 1.15 times, higher than that for Sample 1 .

As compared with Sample 1, the effective viscosity in contact is reduced, on average, by 1.53 times at an oil temperature of both $20{ }^{\circ} \mathrm{C}$ and $100{ }^{\circ} \mathrm{C}$ and is equal to $2764 \mathrm{~Pa} \cdot \mathrm{s}$ and $3309 \mathrm{~Pa} \cdot \mathrm{s}$, respectively. With increasing temperature during 45 - 50 cycles of operation, a sharp decrease in this parameter to $78 \ldots 240 \mathrm{~Pa} \cdot \mathrm{s}$ was established, which is due to adaptation of the lubricant boundary layers to the temperature change in the friction contact.

The range of change in the shear rate gradient of the lubricating layer $(\gamma)$ in contact at a maximum sliding speed of $0.71 \mathrm{~m} / \mathrm{s}$ in the conditions of rolling with sliding for Samples 1 and 2 is from $4.5 \cdot 10^{3}$ to $5.73 \cdot 10^{5} \mathrm{~s}^{-1}$.

The formation of boundary films of lubricant with structural adaptability of the triboconjuction elements can lead to mechanical, physical and chemical changes in the surface layers of the metal, which can significantly affect the wear resistance of the contact surfaces. Analysis of changes in microhardness of the surface layers of steel 30KhHSA after 100 cycles revealed the dependence of this parameter on the type of test material. When using Sample 1 as a lubricant, strengthening of both leading and lagging surfaces was fixed. In particular, microhardness of the surface layers of the metal was increased by 512 and $517 \mathrm{MPa}$ for the leading and lagging surfaces, respectively. In the case of using Sample 2, the leading surface of the metal was softened (decrease in microhardness upon testing was $696 \mathrm{MPa}$ ), while the lagging surface was strengthened (increase in microhardness was $444 \mathrm{MPa}$ ).

According to the data of the producers of Samples 1 and 2, they have the same base (mineral oil on the basis of deeply dearomatized low-solidificated fraction, which is obtained from hydrocracking products of a mixture of paraffinic oils and consists of naphthenic and isoparaffinic hydrocarbons). That is why it is active components of additives to Samples 1 and 2 that affect the kinetics of changes in microhardness of surface layers activated under friction. The additives present in Sample 1 are characterized by more effective antiwear properties and thus increase the wear resistance of contact surfaces in the conditions of rolling with sliding.

\section{Conclusions}

Sample 1 of oil "Bora B" AMG-10 (production: LLC "Bora B", TU U 19.2-38474081-010: 2016 with change 1) is characterized by more effective lubricating and rheological characteristics in nonstationary conditions of friction in the rolling with $30 \%$ sliding mode as compared to Sample 2 of AMG-10 oil (production: LLC NPP Kvalitet, GOST 6794-75 with changes1 - 5) according to the following criteria.

1. With Sample 1, there was not fixed any failure of the lubricating layer during start-up and direct metal contact of the friction surfaces. A semidry lubrication mode was only for a short time, during the periods of running-in and initial temperature rise. At start-up, regardless of the temperature of the lubricant, a mixed lubrication mode dominates, while at the maximum rotation speeds of the investigated samples a hydrodynamic lubrication mode dominates.

2. At a volumetric oil temperature of 20 and $100{ }^{\circ} \mathrm{C}$, the thickness of boundary adsorption layers is 1.44 times that for Sample 2.

3. Sample 1 is characterized by low shear stresses, on average $9.4 \mathrm{MPa}$, regardless of oil temperature, and high effective viscosity, on average, 4249 and $5039 \mathrm{~Pa} \cdot \mathrm{s}$ at volumetric oil temperature 20 and $100{ }^{\circ} \mathrm{C}$, respectively.

4. Additives present in "Bora B" AMG-10 oil (Sample 1) are characterized by more effective antiwear properties and increase wear resistance of contact surfaces in the conditions of rolling with sliding due to strengthening of surface layers of metal during operation, while in Sample 2 hardening-softening processes have been established, which cause a decrease in wear resistance of friction pairs.

\section{References}

1 Ezhov V. M. (2017) Razrabotka raschetno-eksperimental'nogo kompleksa dlya sozdaniya smazochnyh i gidravlicheskih masel novogo pokoleniya dlya aviacionnoj tekhniki avtoref. dis. ... kand. tekhn. nauk : 05.07.10 - innovacionnye tekhnologii v aerokosmicheskoj deyatel'nosti, Moskva, 20.

2. Raskin, YU.E., Denisov, YU.I., Vizhankov, E.M. (2004) Diagnostika i kontrol' resursa primeneniya rabochih zhidkostej v gidrosistemah aviacionnoj tekhniki. Kontrol'. Diagnostika, №5, 3-4.

3. CHernozhukov N.I. (1978) Tekhnologiya pererabotki nefti i gaza. CHast' 3. Ochistka i razdelenie neftyanogo syr'ya, proizvodstvo tovarnyh nefteproduktov. Himiya, Moskva, 424.

4. Murashchenko, A.M. (2017) Doslidzhennya gidravlichnih kanaliv pri nestabil'nih temperaturnih umovah. Materiali XXII Mizhnar. nauk.-tekh. konf. «Gidroaeromekhanika v inzhenernij praktici» : tezi dop., Kiïv, $179-186$.

5. Mikosianchyk O.O., Yakobchuk O.Ye., Mnatsakanov R. H., Khimko A.M. (2021) Evaluation of operational properties of aviation oils by tribological parameters. Problems of Tribology, V. 26, No 1/99, 43-50. 
Ільїна О. А., Мікосянчик О. О., Мнацаканов Р.Г., Якобчук О.Є. Розробка методики оцінки якості змащувальних властивостей гідравлічних авіаційних олив.

Розроблено методику оцінки змащувальних та реологічних властивостей гідравлічних олив в триботехнічному контакті, яка полягає в дослідженні зразків товарних партій олив на програмноапаратному комплексі 3 візуальною оцінкою кінетики зміни основних триботехнічних показників фрикційного контакту в режимі on-line. За допомогою роликової аналогії моделюється робота зубчастих передач в умовах кочення 3 проковзуванням 30\%. Проаналізовано зразки оливи АМГ-10 двох виробників. Встановлено, що при зростанні температури мастильного матеріалу для зразка № 2 відбувається тривале відновлення захисних граничних плівок оливи, період їх формування збільшується в 2,5 рази, обумовлюючи реалізацію напівсухого режиму мащення при пуску. Загальна товщина мастильного шару в 1,27 разів менше, в порівнянні з оливою «Бора Б» АМГ-10 (зразок №1), незалежно від температури мастильного матеріалу. Визначено реологічні властивості олив та встановлені для оливи «Бора Б» АМГ-10 низькі напруження зсуву на рівні 9,4 МПа та висока ефективна в'язкість - 4249 та 5039 Па·с при об'ємній температурі оливи 20 та $100{ }^{\circ} \mathrm{C}$ відповідно. Для зразка № 2 при зростанні температури оливи до $100{ }^{\circ} \mathrm{C}$ напруження зсуву збільшується в 1,15 разів, ефективна в'язкість в контакті знижується в 1,53 рази. Присадки, наявні в оливі «Бора Б» АМГ-10, характеризуються більш ефективними протизношувальними властивостями та обумовлюють підвищення зносостійкості контактних поверхонь в умовах кочення з проковзуванням за рахунок зміцнення поверхневих шарів металу при напрацювання, для зразка № 2 встановлені процеси зміцнення - знеміцнення, що обумовлюють зниження зносостійкості пар тертя.

Ключові слова: авіаційні оливи, змащувальний шар, режим мащення, ефективна в'язкість, мікротвердість. 